[Vicino Oriente XXII (2018), pp. 153-162]

\title{
A STUCCO MERLON FROM THE CONGREGATIONAL MOSQUE OF SIRAF AT THE BRITISH MUSEUM
}

\author{
Andrea Luigi Corsi - Sapienza University of Rome
}

\begin{abstract}
This paper deals with the stucco merlon uncovered by D. Whitehouse at Siraf in 1969, currently on view in the Gallery of Islamic Art at The British Museum in London, which has not yet been fully studied. On the basis of both its decorative and technical aspects, as well as the context in which it was found, its manufacturing likely relates to the main reconstruction works - carried out at Siraf after the devastating earthquake of 977 - characterised by the introduction of a new local moulded stucco production.
\end{abstract}

Keywords: Siraf; Congregational Mosque; Abbasid Period; stucco merlon; British Museum

\section{THE MERLON AT THE BRITISH MUSEUM}

The excavations at Siraf directed by David Whitehouse took place between 1966 and 1973 with the support of the British Institute of Persian Studies and the British Museum. ${ }^{1}$ A large amount of the findings are kept at the British Museum and include an almost fully intact stucco merlon found during the excavations at the Congregational Mosque (fig. 1). This merlon is currently on view at the Gallery of Islamic Art. The object (fig. 2), probably acc. no. 2007,6001.16147, ${ }^{2}$ is a three-stepped merlon $42 \mathrm{~cm}$ high, $20 \mathrm{~cm}$ wide and approximately $5 \mathrm{~cm}$ thick. It bears some damage on the borders and was restored before the publication of the volume Siraf III in $1980 .^{3}$ The decoration is moulded ${ }^{4}$ and is composed of stylised vegetal elements. An axial stalk, with a curvilinear course, divides the composition into two almost specular parts. Different vegetal types are combined, creating an 'unrealistic' composition. Five-lobed vine leaves appear inside the lower circular scrolls in the first step of the merlon and in the upper elongated scrolls; their forms are decorated by tiny veins in very low relief. In the second step, a pair of four-lobed elements flank the central vine leaf, again with veins in low relief. Elongated leaves and small tendrils fill the spaces inside and outside the scrolls. The composition is closed on its apex by what appears to be a palmette leaf or blossom flanked by two tendrils, decorated with curvilinear veins. An irregular frame emphasizes the borders. ${ }^{5}$ Although the stucco findings relating to the mosque were not found in situ, the object should be assigned to the second phase of the

\footnotetext{
For the annual reports, see Whitehouse (1967 to 1975). For the Mosque in particular, see Whitehouse (1980). The picture of the merlon is associated with another inventory (no. 1937,0219.11), but the description of the latter does not fit the actual object.

http://www.britishmuseum.org/research/collection_online/collection_object_details.aspx?objectId=217495\&p $\operatorname{artId}=1 \&$ searchText $=$ stucco\&page $=3$. URL visited on 03 May 2018.

3 Whitehouse 1980.

4 The use of a mould to facilitate the work has been suggested (Whitehouse 2009, 26), since two fragmentary merlons with the same decoration were recovered (Whitehouse 1969, pl. VII:b), but it is likely that the finished work needed a second stage of handmade refinements.

5 The irregularity of the borders probably depended on an inaccurate use of the mould, as can be observed in the stucco remains over the frame. Thus, it may be suggested that the merlon was shaped by cutting the outline after the mould was impressed on the fresh stucco.
} 
building, i.e. between 850 and $1150,{ }^{6}$ and considered part of the decorative cresting of the main enclosure.

\section{THE FINDING CONTEXT (THE MOSQUE)}

The Congregational Mosque in Siraf (located in site 'B' of the excavated area, fig. 1) underwent several reconstructions and additions assigned to three main phases. The first two were very close in time: from ca. 825 to 850 and ca. 850 to $1150 .^{8}$ The definitive outline of the Mosque was probably accomplished during the latter phase, with the addition of the SE extension and the ablution area. The third phase is assigned to the period 11501200 and involved the restoration of several parts of the building. ${ }^{9}$ Different types of stucco decorations, characterised by definite changes in techniques and ornamentation, correspond to these phases.

Stucco fragments were unearthed at the Mosque site (B) during the first campaign (1966). They consisted of four small pieces of deeply carved stucco representing small vine leaves and were interpreted as part of the mihrāb decoration belonging to the second phase of the building (fig. 3). ${ }^{10}$

The second campaign (1968) brought to light two crenellation fragments outside the NE wall; they have been associated with the decoration of the building's façade. ${ }^{11}$

The merlon discussed in this study was found during the third campaign (1969), buried under the floor of bays M11-12, near the SE wall. The only information we have about this floor is that it should be attributed to a later rebuilding of the SE wall, carried out after the extension had been constructed. ${ }^{12}$ As for the extension, although it is attributed to the longtime span of the second phase, it is not certain whether it was part of the same project that involved the reconstruction of the main enclosure ${ }^{13}$ or if it was added later to the SE side after completion of the works in the main enclosure. ${ }^{14}$ Regretfully, the only possible connection between the main enclosure and the extension, namely the SW corner of the building, has been eroded by the sea. ${ }^{15}$

\section{Whitehouse $1980,3,24$}

Whitehouse 1970,$6 ; 1980,13$

Whitehouse $1980,9,19$. For a re-discussion of the date of the first two phases, see Allen (1982, 189), who proposes a dating around 804 for the first phase, suggesting that the second phase followed not long thereafter.

9 Whitehouse 1980, 19-24.

10 Whitehouse 1968, 11 and pl. VIII:b.

Whitehouse 1969, 44, fig. 8, pl. VII:b.

2 Whitehouse 1970, 6, pl. XI:b. Instead, in a later publication, the object is mentioned by Whitehouse $(1980,13)$ together with the crenellation fragments found outside the NE wall in 1968, with no other information on the context in which it was found.

13 The attribution of the repairs and the construction of both the ablution area and the extension to a single project could be explained, according to Whitehouse $(1980,9)$, by the fact that, after these works, the layout of the mosque would have been based on a square of 55 x 55 metres. In his last work on Siraf, Whitehouse seems to distinguish the reconstruction of the mosque from the building of the extension, suggesting that the crenellation may belong to one of these building campaigns surely undergone before 1147-1148 (Whitehouse 2009, 26).

14 Whitehouse 1970, 2; 1980, 9.

15 Whitehouse 1980,9 . 


\section{TECHNICAL AND DECORATIVE ASPECTS}

The use of stepped merlons for decorative purposes was widespread in Early Islamic architecture and was inherited from earlier Middle Eastern examples. ${ }^{16}$ Many variations can be observed among these architectural elements, as they can differ in shape and number of steps, dimensions, materials and decorative patterns. Two main types can be identified according to the shape of the steps: one with perpendicular and the other with oblique steps, forming an acute angle. ${ }^{17}$ The first kind is typical of ancient examples and is highly employed from the Arabian Peninsula to Iran. ${ }^{18}$

The Siraf merlon belongs to the second type, the most attested in Islamic times since the Umayyad Period. Based on known early examples of crenellation, their dimensions seem to be linked to the material employed: stone merlons from the palace at Khirbat al-Mafjar $(100 \mathrm{~cm}$ high $),{ }^{19}$ the palace at 'Amman (ca. $86 \mathrm{~cm}$ high) ${ }^{20}$ Khirbat al-Minya $(110 \mathrm{~cm}$ high $)^{21}$ and the mosque of Cordoba $(\mathrm{ca} .94 \mathrm{~cm})^{22}$ are considerably larger than stucco merlons like those from the bath in Khirbat al-Mafjar (ca. $20 \mathrm{~cm}$ wide), ${ }^{23}$ Qasr al-Hayr alGharbi (67 and $60 \mathrm{~cm}$ high) ${ }^{24}$ and the palace ' $C$ ' in Raqqa (ca. $16 \mathrm{~cm}$ wide) ${ }^{25}$ the dimensions of the Siraf merlon are similar to the latter, being $20 \mathrm{~cm}$ wide. The small number of findings of this kind is probably due to the fragility of the material, amplified by the usual thinness of these decorative merlons. ${ }^{26}$

However, the most interesting aspect of the Siraf merlon is its decoration. It has been suggested that this object, together with the carved stucco fragments representing vine leaves, belonged to the second phase of the mosque ${ }^{27}$ although this phase lasted for more than three centuries. If all those stuccoworks were coeval, two different ways of producing this material were attested in the same period and, what is more, in the same building. The tiny vine leaves are in fact deeply carved into the hardened stucco and can be assigned to the 'miniaturistic type' attested in the early Abbasid Period, ${ }^{28}$ while the vine leaves

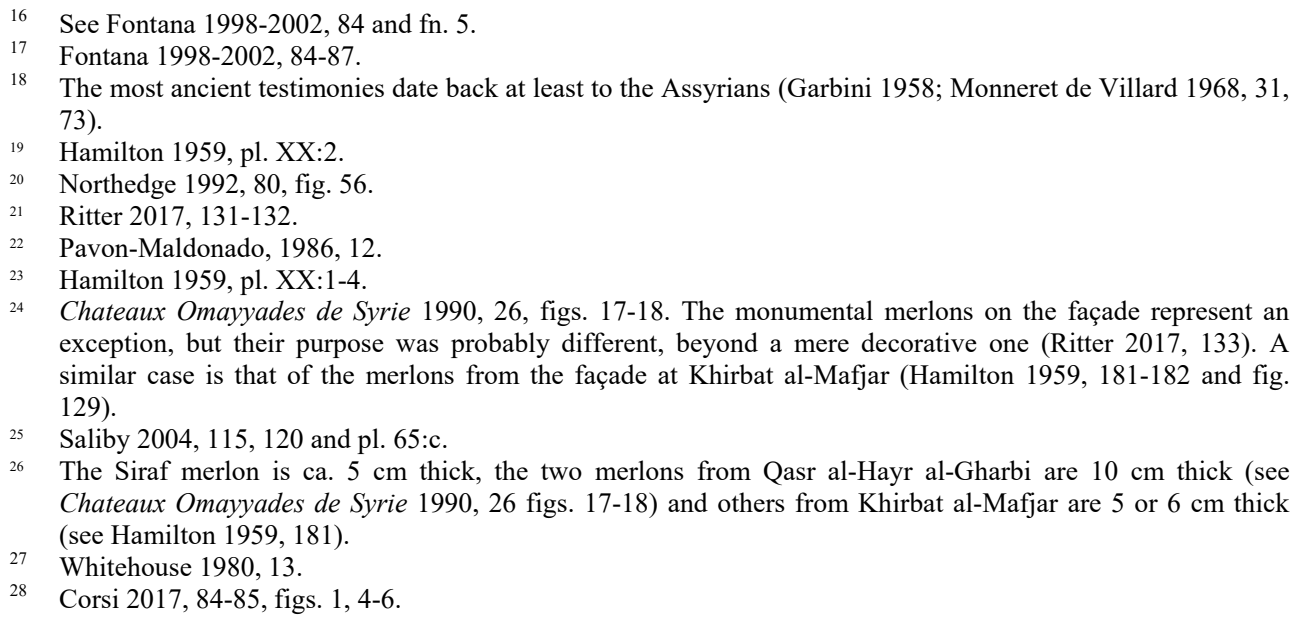

26 The Siraf merlon is ca. $5 \mathrm{~cm}$ thick, the two merlons from Qasr al-Hayr al-Gharbi are $10 \mathrm{~cm}$ thick (see Chateaux Omayyades de Syrie 1990, 26 figs. 17-18) and others from Khirbat al-Mafjar are 5 or $6 \mathrm{~cm}$ thick (see Hamilton 1959, 181)

27 Whitehouse 1980, 13.

28 Corsi 2017, 84-85, figs. 1, 4-6. 
depicted on the merlons are moulded. ${ }^{29}$ The presence of the 'miniaturistic style' relates the early decoration of the Siraf mosque to that of other Iranian mosques like those of Isfahan, Susa and Samarqand, and to the Early Islamic stucco fragments excavated in the palace at Bishapur, where almost identical patterns are attested. ${ }^{30}$ It is worth citing the case of Raqqa, where the use of stepped merlons is known at least for palace $C$, which is roughly coeval to the earliest phase of the mosque of Siraf (built around 800). On the basis of the findings from palace $\mathrm{C}$ in Raqqa it can be observed that the carved technique employed for the stucco panels located on doorposts is the same attested for the stucco merlons, ${ }^{31}$ probably being the work of the same craftsman. In the case of Siraf, the stuccowork techniques employed for the mihrāa decoration and crenellation are different and can be interpreted as works produced by different craftsmen. ${ }^{32}$

\subsection{The British Museum merlon and the moulded stucco production at Siraf}

The technical aspect should be considered the most important for dating the Siraf merlon at the British Museum. Indeed, several panels and fragments of stucco from the Siraf excavations kept in the same museum show similar patterns and low relief moulding. These artefacts (fig. 4) were recovered in a residential area (named ' $F$ ') and attributed by Whitehouse to the period between 977 and $1050 . .^{33}$ In addition to these moulded findings and the merlons from the mosque, another three fragments of probably slightly smaller stucco merlons come from other excavated areas in Siraf and feature a moulded decoration in low relief, thus testifying to the same technique employed for the mosque merlons. ${ }^{34}$ This specific kind of moulded stucco production featuring vegetal elements seems to be

29 According to Whitehouse $(1978,54-55)$ the merlon is the earliest example of moulded stucco vegetal decoration from Siraf.

30 For Isfahan, see Scerrato 2001, fig. 6; for Susa, see Hardy-Guilbert 1990, 287 fig. 8; for Samarqand, see Grenet, Isamiddinov, Bernard 1992, 306-307; for Bishapur, see Ghirshman 1956, 161 and pl. XXII.

31 Moreover, the tiny carved vine leaves on the Raqqa merlons (see Saliby 2004, 115, 120, pl. 65:c) can be compared with the same fragmentary vegetal elements recovered at Siraf, but they substantially differ from the pattern depicted on the British Museum merlon.

32 Although not mentioned by Whitehouse, two other unpublished stucco fragments from the mosque of Siraf (site B) and kept at the British Museum (acc. nos. 2007.6001.15209 and 2007.6001.15181) feature a bevelled decoration resembling Samarra style C, possibly testifying to another decorative phase.

33 Whitehouse $(1969,58-60 ; 1970,15)$ attributes the introduction of a new type of residential building to a reconstruction period, perhaps after an earthquake like that of 977 or 1008 (on these earthquakes in Siraf, see Ambraseys - Melville 1982, 137). However, most houses were abandoned before 1050 (Whitehouse 1970, 1415). These houses were embellished by several moulded stucco panels, found in the debris during the excavations. Panels and fragments are mostly unpublished, and the excavation reports only provide some drawings (see for example Whitehouse 1969, fig. 9); however, several examples are accessible in the British Museum online catalogue: see in particular acc. no. 2007,6001.15206, showing a rendering of the scroll similar to that of the central stalk of the merlon in question. A very similar pattern is to be found on the carved stucco covering the left inner column of the mihrāb of the Friday Mosque in Nā'īn (see Finster 1994, pl. 34:1), dating to 960 ca., thus strengthening the dating attributed by Whitehouse to the stuccoes of the Siraf houses (977-1050). Another interesting fragment from the British Museum on-line collection is acc. no. $2007,6001.15167$ for the shape of the leaf and the latter's low relief veins. Indeed, these features are similar to those employed on the Siraf merlon.

34 These three fragments are kept in the British Museum (acc. nos. 2007,6001.15197-98-99). They come from site $\mathrm{M}$, but there is no information on them in the excavation reports. 
exclusive to Siraf as, in my opinion, no direct comparison can be traced from other coeval Islamic contexts. Considering the impact that Samarra stuccoes had on the production of this material from the mid- $9^{\text {th }}$ century, ${ }^{35}$ the peculiarity of the Siraf examples is even more interesting. The extremely low relief distinguishes the latter from both Samarra styles A and $\mathrm{B}$, characterised by a hand-made carving in high relief, and style $\mathrm{C}$, which shows abstract and repeatedly moulded elements in low relief, in comparison with the vegetal elements depicted in the Siraf moulded stuccoes. As already stated, the mihrāb's tiny carved leaves fit perfectly with the proposed dating of the first and second phase of the Mosque at the beginning of the $9^{\text {th }}$ century, but this cannot be said for the merlon due to its specific style.

It would be useful to reconsider the finding context of the object in order to hypothesise about its dating. During the third phase - begun between 1147-1150 - and after the restoration of the SE wall in correspondence with bays 12 to 15 , bays M11-12 received a new flooring that sealed the stucco merlon. ${ }^{36}$ For this reason, we know that the merlon was buried around 1150, but we lack information to determine how long it remained in situ. It could be suggested that the production of the Siraf merlon is associated with the later low relief moulding technique, widely used for the stuccoes from houses dated between $977^{37}$ and $1050 .{ }^{38}$ The devastating earthquakes of 977 and 1008, most likely one of the reasons for the major reconstruction projects at site $\mathrm{F}$, have also been the cause of some renovations in the mosque ${ }^{39}$ that may have included the creation of a new cresting on the enclosure in a 'style' closer to that used for the contemporary houses. If so, the merlon would have been produced between the end of the $10^{\text {th }}$ and beginning of the $11^{\text {th }}$ century by the same craftsmen working at the houses and represents the latest known decorative intervention on the building. The proposed chronology falls into the period of Buyid rule, when trade through the Persian Gulf increased, especially under 'Adud al-Dawla (949-983), ${ }^{40}$ and the port of Siraf lived its last prosperous years, before the rise of the new port in the island of Kish. ${ }^{41}$ Later on, during the $12^{\text {th }}$ century, significant problems occurred on the SE side of the mosque: indeed, the reconstruction of the SE wall and the backfilling of rooms 11-12 of the extension - done to strengthen the ceiling and upper floor at mosque level - are attested to the same period. ${ }^{42}$

\footnotetext{
Just two fragments that resemble Samarra stuccoes came from the excavations at the Mosque (cf. fn. 32).

Whitehouse (1970, 5-6); the dating of the beginning of the third phase is proposed by Whitehouse $(1980,24)$.

The earthquake caused some of the merchants to leave the town (Whitehouse 1976, 42). This event is reported by Whitehouse also in relation to restorations of the mosque fabric (Whitehouse 1969, 44).

38 This is the date the houses were finally abandoned (Whitehouse 1970, 15). Whitehouse $(1976,42)$ refers this event to the collapse of the Buyids, ca. 1055, which ended Siraf's fortune as an international port.

39 Whitehouse $(1969,44)$ : the introduction of buttresses and the frequent restorations of the qibli wall of period 2 are due to the decay, hastened by earthquakes like that of 977.

40 Potter 2005, 36

41 Whitehouse 2009, 14-15.

42 Whitehouse 1970,$5 ; 1980,22-23$. It was at this moment that the merlon has been sealed by the new flooring.
} 


\section{CONCLUSIONS}

In conclusion, the chronological attribution proposed for the British Museum merlon remains in the time span assumed by Whitehouse, i.e. the second phase of the building (ca. 850 to 1150), though a narrower time span for its dating is here suggested, namely between 977 and the beginning of the $11^{\text {th }}$ century. This attribution is based on observations related to artistic and technical elements, for which the closest comparisons can be found in late $10^{\text {th }}$ and $11^{\text {th }}$-century stuccoes from the residential areas of the town. The earthquakes of 977 and 1008 played an important role in the history of Siraf, as testified both by ancient sources and traces of reconstructions throughout the town. The moulded technique employed for the stucco panels of the houses has been related, by Whitehouse, to the reconstruction plan of the residential area after those earthquakes. The local craftsmanship involved in the decoration of the houses may have been responsible even for the new cresting of the mosque during this renovation period. Regarding the Congregational Mosque, the three different 'styles' of stuccowork here attested should probably be linked to the sequence of restoration phases that characterise the history of the building, testifying to dynamic changes in ornamental taste, which involved the use of different techniques. The most interesting aspect of these three 'styles' lies in the adaptation of the earlier two to the widespread patterns of the early Abbasid Period, followed by the introduction, probably during the Buyid Period, of a new and local taste. The latter flourished during a prosperous moment for the town, shortly before it fell into disrepair. The Siraf merlon at the British Museum is probably the finest example of this local tradition and, at the same time, the latest decorative element of the Congregational Mosque. The merlon remained in situ until ca. 1150 when new works to strengthen the mosque structure became necessary again, during the definitive decline of the city. ${ }^{43}$ There is no trace of later decoration from this last phase of the mosque, but this is likely due to the widespread abandonment of the city after 1050 .

\section{REFERENCES}

AlLEN, T.

1982 Reviewed Work: Siraf III: The Congregational Mosque and Other Mosques from the Ninth to the Twelfth Centuries by David Whitehouse: Ars Orientalis 13 (1982), pp. 188189.

Ambraseys, N.N. - Melville, C.P.

1982 A History of Persian Earthquakes, Cambridge 1982

CHATEAUX OMAYYADES DE SYRIE

1990 Chateaux Omayyades de Syrie, Collections du Musée National de Damas (1990-1991), Paris 1990.

CORSI, A.L.

2017 A Brief Note on Early Abbasid Stucco Decoration. Madinat al-Far and the First Friday Mosque of Isfahan: Vicino Oriente XXI (2017), pp. 83-95.

43 The city was already in ruins, but the mosque was still in use in 1218: see Yaqut 1861, 331-332; Whitehouse 2005,4 . 
FINSTER, B.

$1994 \quad$ Frühe Iranische Moscheen, Berlin 1994.

FONTANA, M.V.

1998-2002 L'eredità islamica del coronamento con merli di Palazzo Corigliano e di alcuni edifici GARBINI, G. napoletani fra Rinascimento e Barocco: Studi Magrebini XXVI (1998-2002), pp. 83-96.

1958 The Stepped Pinnacle in Ancient Near East: East and West 9/1-2 (1958), pp. 85-91.

GHIRSHMAN, R.

$1956 \quad$ Fouilles de Chapour: Bîchâpour. Vol. II, Les mosaïques sassanides, Paris 1956.

GRENET, F. - ISAMIDDINOV, M. - BERNARD, P.

1992 Fouilles de la mission franco-ouzbèque à l'ancienne Samarkand (Afrasiab) en 1990 et 1991: Comptes rendus des séances de l'Académie des Inscriptions et Belles-Lettres 136/2 (1992), pp. 275-311.

HAMILTON, R.W.

1959 Khirbat al-Mafjar. An Arabian Mansion in the Jordan Valley, Oxford.

HARDY-GUILBERT, CL.

1990 Stucs islamiques de Susa: F. Vallat (ed.), Contributions à l'histoire de l'Iran: Mélanges offerts à Jean Perrot, Paris 1990, pp. 269-293.

MONNERET DE VILLARD, U.

1968 Introduzione allo studio dell'archeologia islamica. Le origini e il periodo omayyade, Venezia 1968.

NORTHEDGE, A

1992 Studies on Roman and Islamic 'Ammān, Vol. 1, History, Site and Architecture, Oxford 1992.

PAVON-MALDONADO, B.

1986 Las almenas decorativas hispanomusulmanas, Madrid 1986.

POTTER, L.

2005 The Port of Siraf: Historical Memory and Iran's role in the Persian Gulf: Proceedings of the International Congress of Siraf Port, Bushehr 2005, pp. 28-49.

RITTER, M.

2017 Der umayyadische Palast des 8. Jahrhunderts in Hirbat al-Minya am See von Tiberias (Studien zur islamischen Kunst und Archäologie 1), Wiesbaden 2017.

SALIBY, N.

2004 Les fouilles du Palais C 1953: V. DAIBER - A. BeCKer (eds.), Raqqa III. Baudenkmäler SCERRATO, U und Paläste I, Mainz 2004, pp. 105-120.

2001 Ricerche archeologiche nella Moschea del Venerdì di Isfahan della Missione Archeologica Italiana in Iran dell'IsMEO (1972-1978): Antica Persia. I tesori del Museo Nazionale di Tehran e la ricerca italiana in Iran, Roma 2001, pp. XXXVI- XLIII.

WHITEHOUSE, D.

1967 Survey of Excavations in Iran during 1965-66 (Siraf): Iran 5 (1967), pp. 141-142.

1968 Excavations at Siraf; First Interim Report: Iran 6 (1968), pp. 1-22.

1969 Excavations at Siraf; Second Interim Report: Iran 7 (1969), pp. 39-62.

1970 Excavations at Siraf; Third Interim Report: Iran 8 (1970), pp. 1-18.

1971 Excavations at Siraf; Fourth Interim Report: Iran 9 (1971), pp. 1-17.

1972 Excavations at Siraf; Fifth Interim Report: Iran 10 (1972), pp. 63-87.

1973 Survey of Excavations in Iran 1971-72 (Siraf): Iran 11 (1973), pp. 205-206.

1974 Excavations at Siraf; Sixth Interim Report: Iran 12 (1974), pp. 1-30.

1975 Survey of Excavations in Iran: 1973-74 (Siraf): Iran 13 (1975), p. 187. 
1976 Siraf: A Medieval City on the Persian Gulf: Storia della città. Rivista internazionale di storia urbana e territoriale 1 (1976), pp. 40-55.

1978 Siraf: An Islamic City and its Role in Art: Storia della città. Rivista internazionale di storia urbana e territoriale 7 (1978), pp. 54-58.

1980 Siraf III, The Congregational Mosque and Other Mosques from the Ninth to the Twelfth Centuries, London 1980.

2005 Introduction: Proceedings of the International Congress of Siraf Port, Bushehr 2005, pp. $1-7$.

2009 Siraf: History, Topography and Environment, Oxford 2009.

YAQUT

1861 Kitāb mu'jam al-buldān, Dictionnaire géographique, historique et littéraire de la Perse et des contrées adjacentes: extrait du Mo'djem el-Bouldan de Yaqout et complété à l'aide de documents arabes et persans pour la plupart inédits: CH. BARBIER DE MEYNARD (ed.), Paris 1861. 


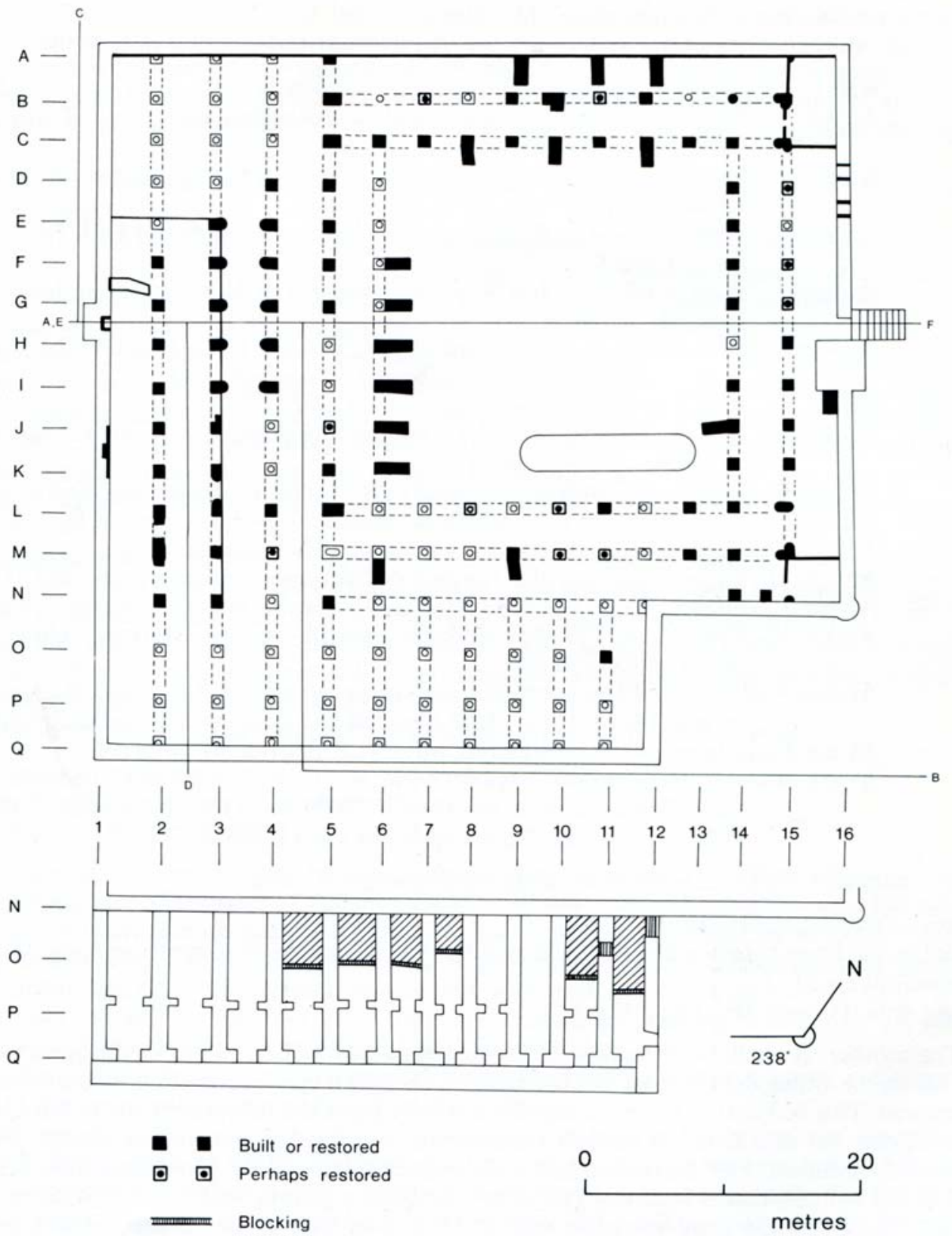

Fig. 1 - Siraf, the plan of the Congregational Mosque after phase 3 (after Whitehouse 1980, fig. 11). 

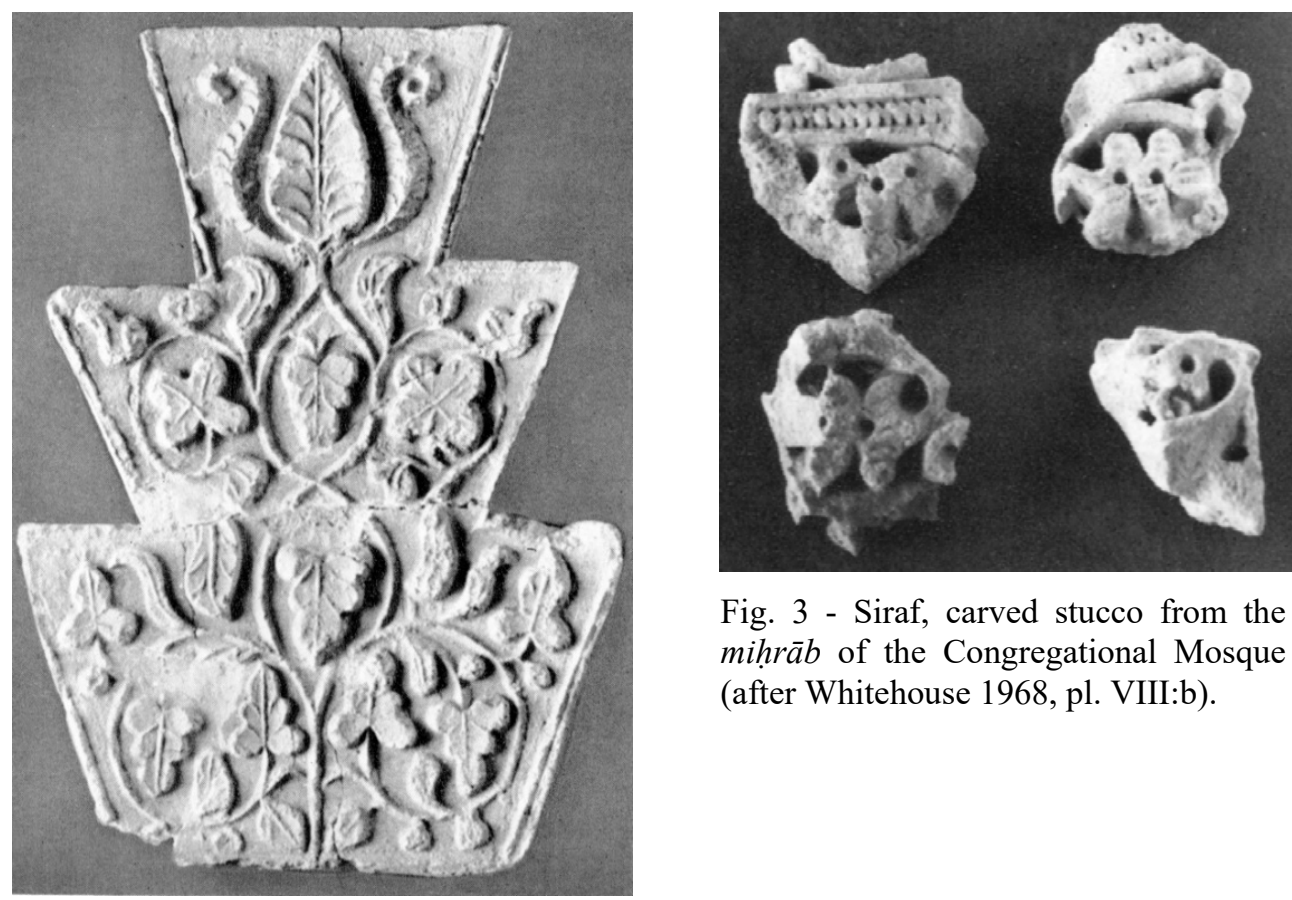

Fig. 3 - Siraf, carved stucco from the mihrā $b$ of the Congregational Mosque (after Whitehouse 1968, pl. VIII:b).

Fig. 2 - Siraf, the merlon from the Congregational Mosque (today in London, British Museum, acc. $\mathrm{n}^{\circ}$ 2007,6001.16147), before restoration (after Whitehouse 1970, pl. XI:b).

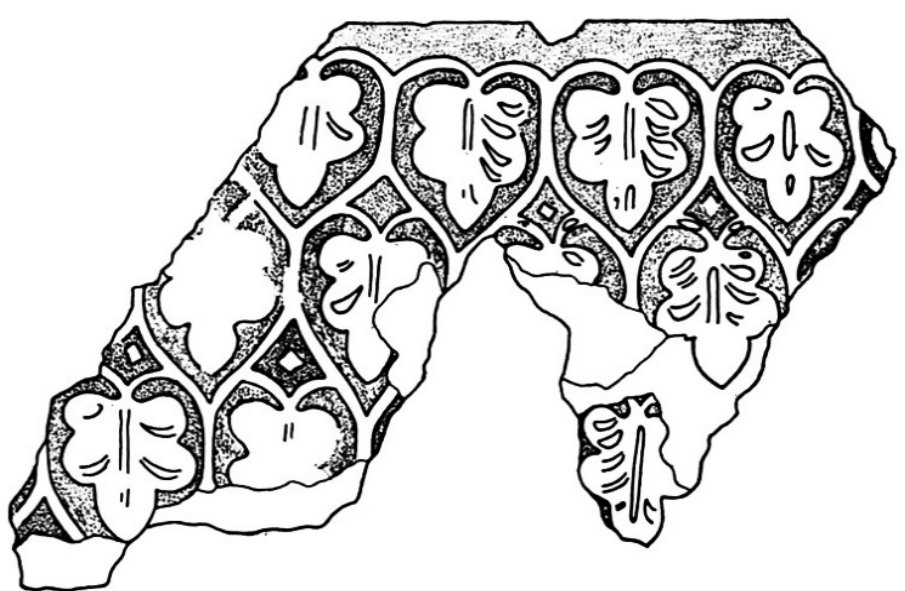

Fig. 4 - Siraf, drawing of a fragmentary stucco panel from site F (after Whitehouse 1969, fig. 9.4). 